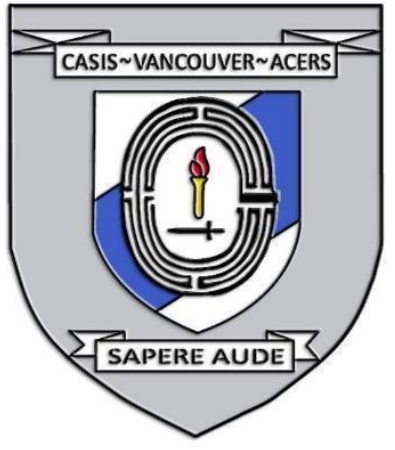

\title{
ISLAMIC EXTREMISM
}

Date: November 25, 2020

Disclaimer: This briefing note contains the encapsulation of views presented by the speaker and does not exclusively represent the views of the Canadian Association for Security and Intelligence Studies.

\section{KEY EVENTS}

On November 25, 2020, Dr. Rizwan Mustafa presented Islamic Extremism at the 2020 CASIS West Coast Security Conference. The presentation was followed by a question and answer period with other speakers. The key points of discussion focused on why understanding the Muslim worldview is important in understanding terrorism, the concept of Jihad and terrorism, and the faith proposition of the Qur'an.

\section{NATURE OF DISCUSSION}

\section{Presentation}

Dr. Mustafa discussed the relationship between the faith proposition within the Qur'an, Jihad, and Islam as a whole. Additionally, Dr. Mustafa discussed how organisations such as Daesh (Islamic State) and Al-Qaeda use Jihad to justify their violent actions.

\section{Question period}

Dr. Mustafa discussed how many religions express his transactional engagement model as a key component of their faith. Additionally, Dr. Mustafa discussed the importance of critically examining the literature that militant Jihadist groups produce to gain further understanding of their ideology and practices. The role that women have played within Daesh was also discussed along with the importance of changing the way in which the Muslim community is engaged with in order to prevent radicalization. 


\section{BACKGROUND}

\section{Presentation}

Understanding the Muslim perspective on the purpose of creation and the larger Muslim worldview is important when considering faith inspired violence perpetrated by groups, such as Daesh and Al-Qaeda. Using the term "Islamist" for violent groups such as Daesh presents a number of problems that Dr. Mustafa attempts to avoid. He prefers to consider them in a larger category of "fate practitioners" who attempt to position their worldview as a bonafide construct of faith. When considering these fate practitioners, it is important to understand the broader context of faith that they are trying to establish their position within.

The purpose of Mankind's creation is at the core of Islamic beliefs and worldview. According to the Qur'an, that purpose is to worship God by fulfilling your obligations. However, this relationship is a transactional arrangement between the individual and God; in return for fulfilling your obligations to worship God within the material realm, your spirit will receive virtue, privilege, and paradise in the spiritual realm. Dr. Mustafa refers to this form of spirituality as the transactional engagement model. In order to be able to fulfill one's obligation to serving God, the first step is a to believe in God, which is at the core of Islam. If an individual does not sincerely believe in God, all other actions that they take are by default outside of the faith. The Qur'an teaches that belief in God will lead to the activation of consciousness, which allows for the actions in fulfilling the obligation to worship God to take place.

When discussing militant forms of Islam, academic and public policy communities often do not position these beliefs within the wider mainstream interpretation of Islam and within the aforementioned transactional engagement model. Militant and violent forms of Jihad, which today are most often associated with violent actions, are no different within some fate practitioner's frameworks of Islam compared to other forms of worship. In fact, many of these practitioners, such as Daesh, preach within their propaganda that Islam is underpinned by the belief in militant Jihad as a fundamental component of fulfilling an individual's obligation to serve God. A Militant Jihad, in their view, thus enables all other realities of Islam and fulfills the purpose of Mankind's creation. When we understand this, we can begin to see the stark deviation that this interpretation of Islam has from the mainstream. In fact, this is why Daesh and other militant Jihadists' find it easy to kill other Muslims; they believe that these other Muslims are failing in their obligation to serve God and are preventing all other realities of Islam.

The Journal of Intelligence, Conflict, and Warfare 


\section{Question Period}

In his research, Dr. Mustafa has found that the transactional engagement model of religious practice is present across multiple religions and time periods all over the world. For example, Judaism and Hinduism involve a similar interdependence between deeds done in the material realm and repercussions in the afterlife. There are some groups such as Daesh that even though they laid their endeavours to theology, are focused entirely on preserving territory. This overwhelmingly becomes evidence that speaks of the starting point of the organisation where they originate from because the theology informs the practice; it begins to rationalise their seeming abhorrence towards everybody else's actions in which they undertake.

Daesh has been more potent and aggressive in their actions than similar groups that came before them, and this is why there was a divorce between Al-Qaeda and Daesh. When we begin to understand how they see the world and what they put into it, this is where the big tech companies and AI leaders can become involved, such as looking into publications, how they produce their narrative, and what is being put out for consumption by the general readership. When an organization like that puts out a publication for the general public, there is always an audience.

The conversation is always conflict oriented. Their contribution and engagement are starting from the point of violence or conflict. It is impossible to understand their reality until you look into their publications, which can entrench their beliefs generationally. The learning materials that Daesh produces for children is close to what is made by Al-Qaeda and the Mujahideen in the 70s and 80s. In the first Daesh publication flagship between 2014 and 2016, there is a reference to a time in Syria that was prophesied as a battleground. By presenting ancient texts to contemporary challenges, it presented a fatalistic view of the future. The iconology, production, narratives, and how they engage the world is conflict laden. That is, somewhere in which data could possibly be translated into some form of algorithm for analysis. Additionally, the materials that Daesh produces have said that the plight of Palestinians is no more important than other issues facing Islam. However, the narrative that the Palestinians are being oppressed and that Israelis are the enemy is prominent within the movement. It would be interesting to look further at the relationship between Palestine, Israel, and Daesh.

For Daesh, women did not play a prominent role in their recruitment or military goals early in their campaign, and this was reflected in their literature, which was 
almost exclusively targeted towards men. However, as the movement developed, their online recruitment efforts increasingly focused on bringing in women to support them, and we saw women from all over the world travel to Syria to join them. The function of these women is to support the infrastructure of Daesh while the men are on the front lines and continue the next generation.

Dr. Mustafa made it clear that it is important to provide safe spaces for people to have conversation, which may mean that they are removed from the security agenda, surveillance, and police. There is an assumption that Imams have the answer to the violence. When you look at violent literature, arguments are presented that are beyond classical literature. It does not talk about the militant perspective, understanding of faith, or the understanding of Sharia Law. Those conversations are stored in specific cases in documentation and to access them is a source of security contention. The starting point is the people that are being focused on in communities, who don't have the answers. If they tried to find the answers, they might be suspected of being adversarial. When you try to create a safe space, it becomes difficult because of the security agenda; yet, that does not mean that creating safe spaces isn't necessary. These issues can only be resolved through extensive security community engagement.

\section{KEY POINTS OF DISCUSSION}

\section{Presentation}

- Understanding the Muslim worldview is important when considering faithinspired violence perpetrated by groups, such as Daesh and Al-Qaeda.

- Islam is a religion with a transactional relationship model between the individual and God. Deeds done in the material realm have consequences in the spiritual one.

- At the core of Islam is the belief that Mankind was created to worship God.

- Militant Jihadism must be analysed within Islam's wider framework and it should be distinguished from the mainstream interpretation of Jihad.

\section{Question period}

- The transactional engagement model of religious practice can be found across multiple religions and time periods all over the world.

- Big tech and AI can help analyse the materials that groups such as Daesh produce. 
- For Daesh, women did not play a prominent role in their recruitment or military goals early in their campaign; however, they did gain a more prominent role later on.

- It is important to provide safe spaces for people to have conversations.

\section{(c) (1) $(9$ \\ EY NC ND This work is licensed under a Creative Commons Attribution- NonCommercial-NoDerivatives 4.0 International License.}

(C) (Rizwan Mustafa, 2021)

Published by the Journal of Intelligence, Conflict, and Warfare and Simon Fraser University

Available from: https://jicw.org/ 